\title{
Removal of Lead Contamination through the Formation of Lead-Nanoplates by a Hot Spring Microbial Protein
}

\author{
Chetana Ghosal, Nurul Alam, Abiral Tamang, Brajadulal Chattopadhyay* \\ Department of Physics, Jadavpur University, Kolkata, India \\ Email: ^bdc_physics@yahoo.co.in
}

How to cite this paper: Ghosal, C., Alam, N., Tamang, A. and Chattopadhyay, B. (2021) Removal of Lead Contamination through the Formation of Lead-Nanoplates by a Hot Spring Microbial Protein. Advances in Microbiology, 11, 681-693. https://doi.org/10.4236/aim.2021.1111049

Received: October 26, 2021

Accepted: November 23, 2021

Published: November 26, 2021

Copyright ( 2021 by author(s) and Scientific Research Publishing Inc. This work is licensed under the Creative Commons Attribution International License (CC BY 4.0).

http://creativecommons.org/licenses/by/4.0/

\section{(c) (i) Open Access}

\begin{abstract}
Lead contamination still remains as serious threat to public health and environment because of its non-biodegradability and toxicity. A clean technique has been developed for removal of lead contamination through the formation of lead-oxide nanoplates using a bacterial protein (Molecular weight $\sim 30 \mathrm{kDa}$ ) as biological template. The isolated hot-spring bacterial (the bacterium was named as MDH1) protein when adding to the solution of lead compound (e.g., lead nitrate), nanoplates of lead-oxide are formed as viewed by electron microscope. The as prepared lead-oxide-nanoplates are characterized by Inductively Coupled Plasma analysis, Energy Dispersive X-ray Spectroscopy and X-ray diffraction analyses. The lead-oxide-nanoplates and the filtered supernatant of the reactive solution both were separately used to observe the inhibition of growth of $E$. coli bacteria on culture plate. Lead-oxide-nanoplates produced clear zone of inhibition on the bacterial growth plate, whereas the filtered supernatant exhibited no such zone on the growth of $E$. coli bacteria revealing the fact that lead contamination was removed from the filtered supernatant. The prepared lead oxide nanoplates also possess dye degradation activity which is the added advantage of the process. The MDH1 bacterial protein acts as biological template which successfully removes lead contamination from lead-solution. The process is a clean and cost-effective one which can be used not only for removal of lead contamination but also for removal of different dyes from environment due to having dye-degradation attribute of the lead-oxide nanoplates.
\end{abstract}

\section{Keywords}

Bacteria, Hot Spring, Protein, Dye Degradation, Lead-Oxide Nanoplates 


\section{Introduction}

There are many heavy metals viz., lead, mercury, arsenic, chromium, cadmium etc. producing various hazardous effects to all over the world in terms of their environmental load and contaminations. These metals are undoubtedly serious causes of concern for our environment and societal health. The main anthropogenic sources of these heavy metal contaminations come from the disposal of untreated or partially treated industrial effluents, various toxic heavy metals containing sewage from different industries, heavy metal-containing fertilizers and pesticides used in agricultural fields etc. [1]. Amongst the various heavy metals or metalloids, Sparks (2004) considered lead (Pb) to be one of the major pollutants for our environment [2]. Several industrial activities, viz., production of batteries, production of pigments, melting of metal as well as manufacturing of lead arsenate insecticides or lead water pipes etc. are considered as the main sources of $\mathrm{Pb}$ contamination in the environment [3]. Several researchers have studied the heavy metal contamination in various Indian rivers. A very high concentration of lead $(\sim 392 \mu \mathrm{g} / \mathrm{L})$ in the downstream water of the Yamuna River [4] and noticeable quantity of iron, lead and manganese etc. in the surface water of the Ganga River around Kolkata are obtained from their studies [5]. The most unfortunate situation is that the data obtained by the scientists against contamination are far exceeded from the limits to use the surface water of the Ganga River around Kolkata for drinking purposes. Exposure of several heavy metals (such as lead, mercury, chromium, arsenic, cadmium etc.) severely affects our health which also includes the prenatal development [6] [7]. Particularly, lead ions $\left(\mathrm{Pb}^{2+}\right)$ cause mental retardation, affect kidney and create anemia in our body [8]. It is one of the most detrimental contaminants released in natural waters that also affect the central nervous system, hemoglobin synthesis, reproductive systems as well as gastrointestinal tract [9]. Airborne lead is poisonous to agricultural food by the deposition on fruits, soils and water [10]. It has also been reported that anemic pregnant women and young children are more susceptible to lead toxicity [11].

In order to make an eco-friendly environment, a clean and healthy atmosphere should be provided to all living systems, which will be free from several toxic heavy metals and other hazardous pollutants contamination. Several technologies and physico-chemical methods have been employed for the removal of heavy metals or heavy metallic ion pollutants from the effluent streams and lands. These are viz., ion exchange [12], adsorption [13], membrane processing [14], reverse osmosis [15], filtration [16], biosorption [17], electro-coagulation [18] etc. These technologies or physico-chemical methods employed for removing potentially harmful heavy metals are often ineffective or expensive particularly when the concentration of heavy metals is very low. Physical separation methods are also unable to separate heavy metal salts which are dissolved in waste water [19]. While biological methods like bioremediation i.e., biosorption or bioaccumulation for removal of heavy metals may be an attractive alternative 
over and above the physico-chemical methods due to its better efficacy and eco-friendliness [20].

The following study has been explored an extracellular bacterial protein (approximate molecular weight $\sim 30 \mathrm{kDa}$ ) which has been used directly for removal of lead contamination from water. The protein is able to form lead oxide nanoplates when adding to the lead containing salts (e.g., nitrate solution). The lead oxide nanoplates are insoluble and thus easily precipitated at the bottom and separated out by filtration. The as prepared nanoplates can be exploited against dye degradation for having its photo-catalytic activity. This is an added advantage of this study.

\section{Materials and Methods}

The bacterial strain MDH1 (GenBank accession number: KT600031) has been isolated from a virgin hot spring of Metal Danga, Birbhum District, West Bengal, India and named as MDH1 and characterized in our laboratory [21]. The bacterial strain was purified through serial dilution technique and maintained by culturing in a semi-synthetic medium in our laboratory as described earlier [21]. Phylogenetic analysis of MDH1 strain has revealed that the bacterium is associated to the family "Pseudomonadaceae" with $99 \%$ homologous to Pseudomonas putida H8234. The bacterium is non-pathogenic, gram negative, coccoid shaped and facultative-anaerobic. Lead nitrate was purchased from Sigma-Aldrich. Methyl Orange (MO) and Bromophenol blue (BB) dye were purchased from Merck, Germany. Millipore deionized water was used in this study.

\section{Isolation and purification of bacterial protein}

The bacterium MDH1has been seen to secrete some extra cellular proteins in its growth medium. The desired protein was isolated from MDH1 bacterium cultured medium (6 - 7 days old), concentrated through lyophilization and purified through double-step Sephadex G-100 column chromatographic purification technique [22]. This purified protein was used in aqueous lead nitrate $\left[\mathrm{Pb}\left(\mathrm{NO}_{3}\right)_{2}\right]$ solution $(0.6 \mathrm{M})$ for the removal of lead from the solution through the formation of lead oxide nanoplates.

\section{Removal of lead form lead nitrate solution}

About $100 \mu \mathrm{g}$ bacterial (MDH1) protein powder was added to $100 \mathrm{ml}$ lead nitrate precursor solution $\left[0.6 \mathrm{MPb}\left(\mathrm{NO}_{3}\right)_{2}\right]$ and kept at ambient temperature $\left(37^{\circ} \mathrm{C}\right)$ for 24 hours. A white precipitation was formed which was collected through centrifugation at $4000 \mathrm{~g}$ using Eltek centrifugation machine (TC 4100D). The supernatant was collected through filtration (Whatmann filter paper) and dried at room temperature to get the powder sample for morphological and other experimental studies. The supernatant was stored for further analysis.

Identification of lead oxide precipitate

Inductively Coupled Plasma (ICP-OES Optima 2100 DV, Perkin-Elimer) data analysis was done to confirm the removal of lead from its solution through interaction with the bacterial (MDH1) protein. The morphological characterization 
of the precipitate was done by Field Emission Scanning Electron Microscope (FESEM, FEI, INSPECT F50) as well as by Transmission Electron Microscope (JEOL JEM 2100F). Energy Dispersive Spectrometer (EDX) analysis was performed for elementary detection of the nanoplates sample. The crystallographic properties of lead precipitate were studied by using X-ray diffraction (XRD) measured by $\mathrm{X}$-ray diffractometer (Bruker, $\mathrm{D} 8$ Advance) with $\mathrm{CuK}_{\alpha}$ radiation $(\lambda$ $=1.54 \AA$ ) operated at $40 \mathrm{kV}$ voltage and $40 \mathrm{~mA}$ current. Fourier Transform Infrared Spectroscopy (FTIR) spectroscopy in Attenuated Total Reflection (A529-P/ QMIRacle-ATR-unit, Bruker) mode with $4 \mathrm{~cm}^{-1}$ spectral resolution was employed to identify the functional groups present in the lead precipitate.

Toxicity study of the supernatant on bacterial growth

The supernatant of the reaction solution was separated from lead oxide precipitate through centrifugation followed by filtration through Whatmann filter paper. The toxic nature of the lead ions and the supernatant were studied by observing the zone of inhibition on E. coli (JMJ 101) bacterial growth in Luria-Broth (LB) agar plate. LB medium containing agar (1.5\%) was poured into Petri disc and allowed to get solidified. $100 \mu \mathrm{l}$ of pre-grown $E$. coli culture was spread on the agar plate and left at room temperature for at least $15 \mathrm{~min}$. Three exactly identical wells were made on the agar plate using the cork borer under sterilized condition. One well was filled with $50 \mu \mathrm{l}$ of $0.6 \mathrm{M} \mathrm{Pb}\left(\mathrm{NO}_{3}\right)_{2}$ solution and the rest of two wells were filled with different volumes of supernatant $(20 \mu \mathrm{l}$ and $50 \mu \mathrm{l}$ ). The supernatant was obtained after removing the lead oxide nanoplates by filtration as stated earlier. The Petri agar plate was kept for incubation at $37^{\circ} \mathrm{C}$ for $24 \mathrm{~h}$. After the stipulated time period, the zone of inhibition produced at the well was observed and photographed.

Photo-Catalytic activity of lead oxide

The photo catalytic activity of the lead precipitate was demonstrated by degrading hazardous dyes like Methyl Orange (MO) and Bromophenol Blue (BB). At first, $50 \mathrm{mg}$ of each dye was added to $1 \mathrm{~L}$ of distilled water and used as stock solution. After that, $10 \mathrm{mg}$ of powdered lead precipitate was added to $100 \mathrm{ml}$ of each dye solution and mixed on magnetic stirrer for 15 minutes. $3 \mathrm{ml}$ of the mixed solution was used to evaluate the catalytic degradation of each dye by measuring the corresponding absorbance spectrum of those dyes (300 - $700 \mathrm{~nm}$ ) at different time intervals in UV-Visible Spectrophotometer (ELICO, SL 210). Degradation percentage of $\mathrm{MB}$ and $\mathrm{BB}$ dye in presence of lead oxide nanoplates was calculated through the formula:

$$
\% \text { of Degradation }=\frac{\left(C_{0}-C\right)}{C_{0}} \times 100
$$

where $C_{0}$ is the initial concentration of dye solution and $C$ is the concentration of dye solution in presence of lead oxide nanoplates in different time intervals.

\section{Results}

The protein used in this work was isolated from the well grown MDH1 bacterial 
cultured medium and purified through double steps purification of Sephadex G-100 column chromatographic technique (Figure 1). SDS-PAGE analysis showed that the molecular weight of the isolated protein was $30 \mathrm{kDa}$ approximately. The protein when added to lead nitrate solution, formed a grey colour precipitate (Figure 2(a) and Figure 2(b)). The precipitate was separated through centrifugation followed by filtration through Whatman filter paper (25 $\mathrm{mm}$ ) and dried to make powder form as shown in Figure 2. Abundance of lead was detected in the precipitated powder when analyzed by ICP spectrum analysis of the sample (Figure 2). The morphological structure of the powder precipitate was detected by FESEM and TEM analyses and the photomicrographs of the powder precipitate are shown in Figure 3. The photomicrograph of FESEM (Figure 3(a)) and that of TEM (Figure 3(b)) clearly confirmed the presence of nanoplates like structures in the precipitate. The thickness of the plates was measured from 20 to $25 \mathrm{~nm}$. The FTIR spectrum of the as prepared precipitate confirmed the presence of different chemically functional groups in the lead oxide nanoplates (Figure 4). The FTIR spectra of the powder precipitate also exhibited the presence of Amide I and Amide II bonds as seen in Figure 4, which appeared due to the addition of microbial protein to the lead nitrate solution. The very sharp peaks of the XRD pattern of the powder precipitate similarly suggested that as prepared precipitate was crystalline in nature (Figure 5).
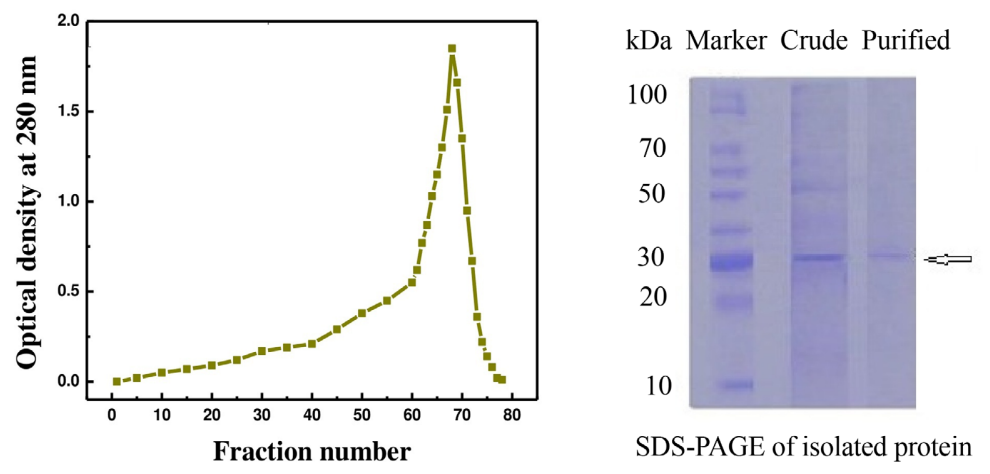

Figure 1. Purification and molecular weight determination of the protein.

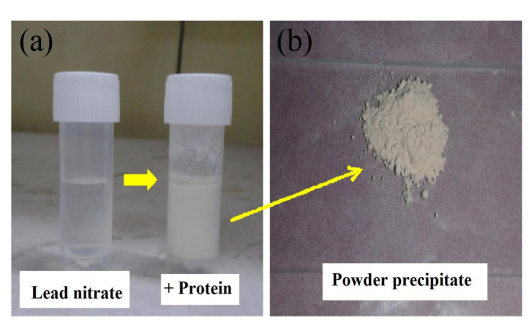

(a)

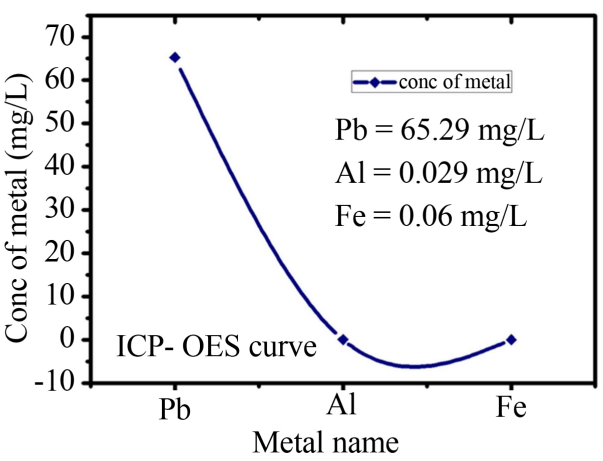

(c)

Figure 2. (a) and (b) Preparation of lead oxide precipitate; (c) ICP-OES characterization of lead oxide precipitate. 


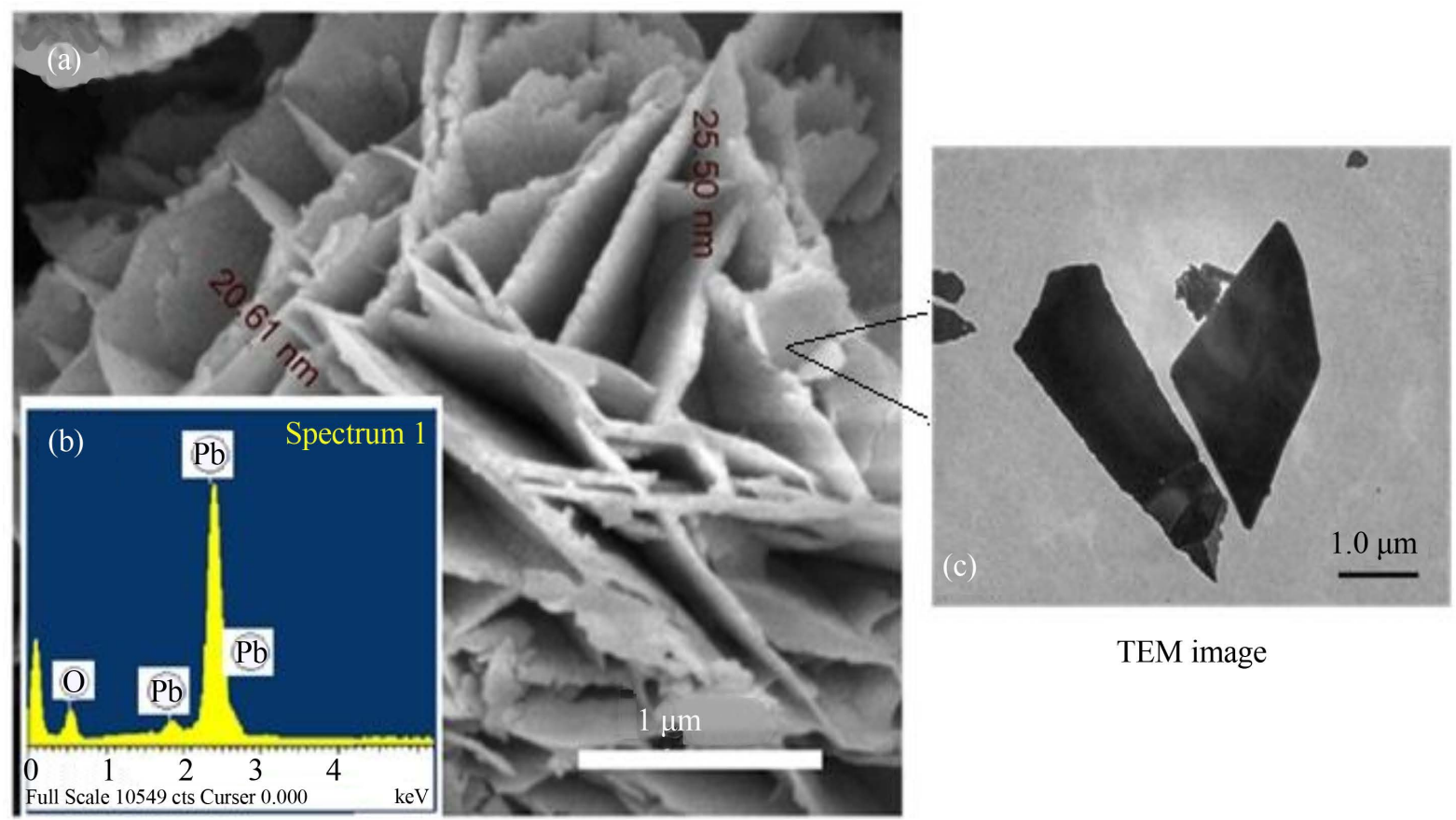

Figure 3. (a) FESEM image of lead oxide nanoplates; (b) EDX spectra of the nanoplates in the Inset of (a); (c) TEM image of lead oxide nanoplates.

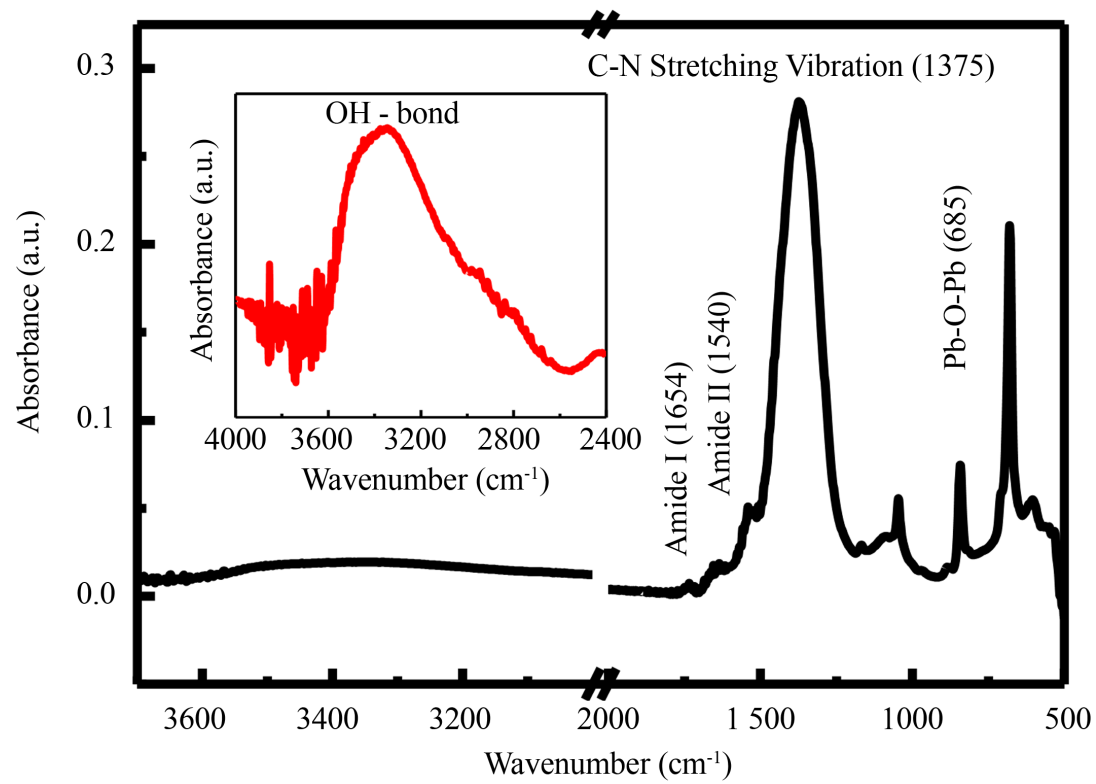

Figure 4. FTIR spectrum of lead oxide nanoplates. Inset shows the enlarged view of stretching vibration of $\mathrm{OH}$ bond.

Lead nitrate assisted zone of inhibition in the growth plate of $E$. coli (JMJ101) bacterial cells was shown in Figure 6. There was no such zone of inhibition observed when only supernatant was added to the wells of the bacterial growth agar plate (Figure 6). The as prepared lead oxide nanoplates possess the photo-catalytic activity due which it degraded methyl orange and bromophenol blue dyes which were described in Figures 7(a)-(d) respectively. 


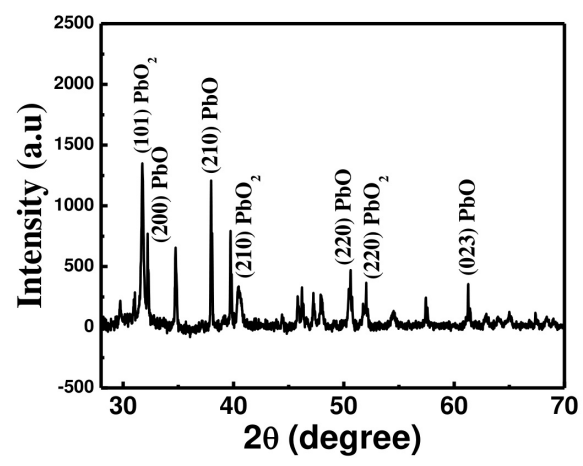

Figure 5. X-ray diffraction pattern of lead oxide nanoplates.

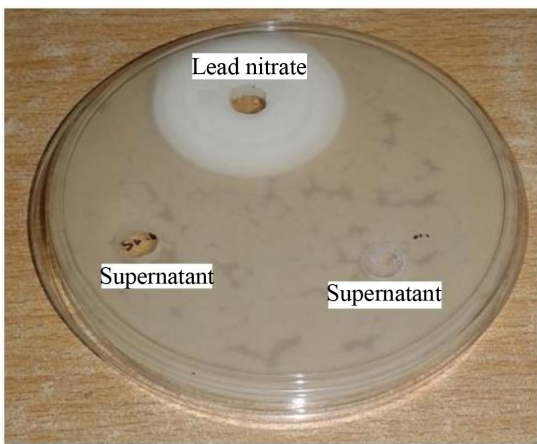

Figure 6. Zone of inhibition showing the non-toxic effect of the supernatant (which was obtained after removal of the lead ions by the precipitation of lead oxide nanoplates) on E. coli (JMJ 101) bacterial growth.

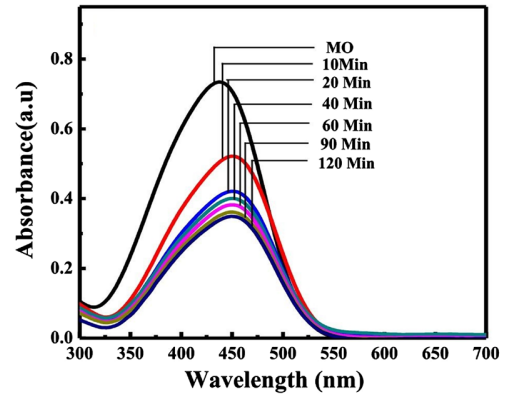

(a)

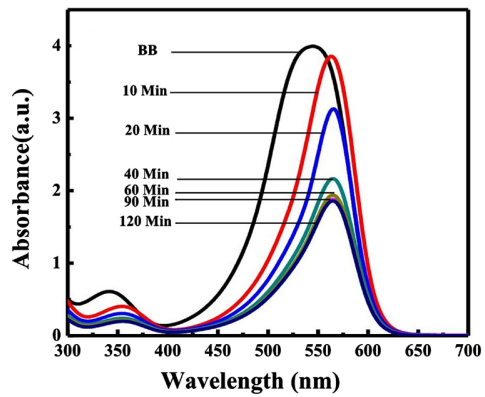

(c)

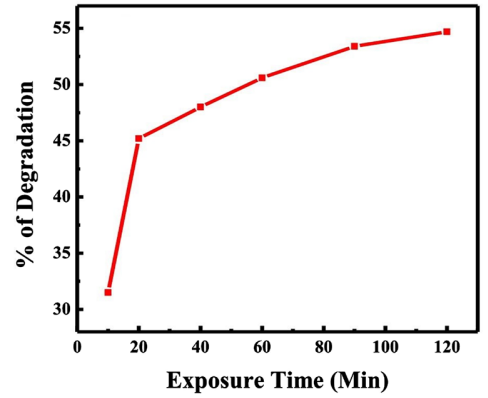

(b)

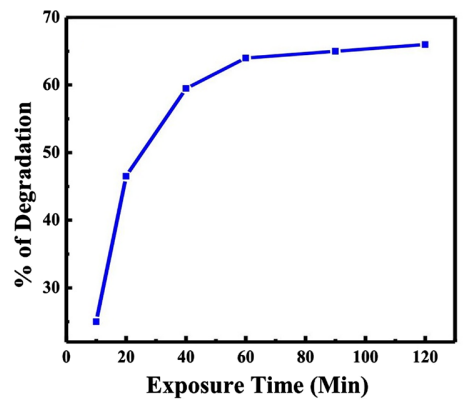

(d)

Figure 7. Photo-catalytic activity of the lead oxide nanoplates. where (a) Degradation of MO dye; (b) Degradation of BB dye; (c) \% of Degradation of MO dye; (d) \% Degradation of BB dye. 


\section{Discussion}

Heavy metals or metalloids are harmful to all living organisms because of their tendency to accumulate inside the biological system. It remains there over a prolong period that causes several complications against survival. However, it is well known that a number of phytochemicals as well microorganisms are able to remove several heavy metals both from human beings and surroundings. Gu et al. (2017) have suggested a plausible microbiological process to remove metals from water [23]. Several bacteria are able to remove mercury from the sediment at a much higher rate of adsorption [24] [25]. Inorganic lead compounds are transformed into volatile tetra-methyl lead by some specific microorganism under anaerobic conditions [26]. Al-Rubaie and Al-Kubaisi (2015) have published a paper where they have described a process of lead removal from water by using aquatic plants [27]. Here an easy and amicable method is developed for removal of lead contamination which would be beneficial for us.

The process is comprised with the addition of a microbial protein to the lead nitrate solution. The protein was isolated from the well grown MDH1 bacterial cultured medium and purified through double steps Sephadex G-100 column chromatographic technique. The protein is secreted by the MDH1 bacteria and its molecular weight is approximately $30 \mathrm{kDa}$ (Figure 1). The protein when adding to the lead nitrate solution, forms a precipitate which is grey in colour and insoluble in water (Figure 2). The as prepared precipitate was separated through centrifugation and followed by filtration through Wahtmann filter paper and dried to make powder form. The ICP-OES spectrum of the powder precipitate confirmed that there was abundance of elementary lead present in the precipitated sample which was formed by the action of MDH1 microbial protein and lead nitrate solution (Figure 2). ICP-OES is one of the most versatile methods for inorganic elemental analysis and use to determine the concentration of the heavy metals present in the solution [28]. Several bacterial strains (such as BKH1, BKH2, BKH4 etc.) isolated from hot springs of Bakreshwar similarly secrete several proteins in the growth medium which have the characteristic biomineralization property for which these bacteria can be used for the development of high performance self-healed bio-concrete materials [22] [29] [30] [31]. The bacterium BKH1 is also able to produce silver nanoparticles [32]. Similarly, the whole cells of bacterium MDH1 show its ability for formation of gold nanoparticles [21]. Akhtar et al. (2013) has shown the biogenic synthesis of metallic nanoparticles by plant extracts. So the formation of lead nanoplates by the MDH1 bacterial protein is not at all a surprising phenomenon [33].

The morphological structure of the powder precipitate was seen by FESEM and TEM photomicrographs from (Figure 3). FESEM (Figure 3(a)) and TEM (Figure 3(b)) images clearly confirmed the nanoplates like structure present in the precipitate. The thickness of the plates was from 20 to $25 \mathrm{~nm}$. Strong peaks of lead and oxygen only in the EDX spectra of the nanoplates revealed that the as prepared precipitate was the lead-oxide nanoplates. The FTIR spectrum (Figure 
4) of the as prepared precipitate confirmed the presence of some chemically functional groups in the lead oxide nanoplates. A sharp peak at around $685 \mathrm{~cm}^{-1}$ represented the asymmetric bending vibration of $\mathrm{Pb}-\mathrm{O}-\mathrm{Pb}$ bond. A very broad peak appeared at $3100-3600 \mathrm{~cm}^{-1}$ region in the FTIR spectrum was signifying $\mathrm{OH}$ stretching vibration in $\mathrm{H}$-bonded water which is shown in the inset of Figure 4 with enlarged view. Another intense peak at $1375 \mathrm{~cm}^{-1}$ indicated the $\mathrm{C}-\mathrm{N}$ stretching vibration. The FTIR spectra exhibited the presence of Amide I and Amide II bonds as seen in Figure 4, which appeared due to the addition of microbial protein to the lead nitrate solution. The peaks between $1600-1700 \mathrm{~cm}^{-1}$ were the stretching vibration of $\mathrm{C}=\mathrm{O}$ bond of Amide I. The amide II band occurred at $1500-1600 \mathrm{~cm}^{-1}$ and was mainly derived from the $\mathrm{N}-\mathrm{H}$ bending vibration. FTIR study thus confirmed that the Amide I $\left(1654 \mathrm{~cm}^{-1}\right)$ and Amide II $\left(1540 \mathrm{~cm}^{-1}\right)$ both have the stronger ability to bind metallic atoms. It signifies that the protein may be responsible for forming a surface layer on the metallic lead oxide nanoplates that helps in stabilization of lead oxide nanoplates.

The crystalline nature of the powder precipitate was ascertained by XRD analysis (Figure 5). The very sharp peaks in the XRD spectra of powder precipitate are the clear evidence of the crystalline nature of the lead oxide nanoplates. In comparison with standard XRD card (JCPDS data file), the main intense peak at $31.8^{\circ}$ corresponds to the diffraction from (101) lattice plane and peaks at $52^{\circ}$ and $40.4^{\circ}$ correspond to (220) and (210) lattice planes respectively. The XRD analysis of powder precipitate was the clear indication of $\mathrm{PbO}_{2}$ nanoplates formation as per the JCPDS analysis (card no. 080185). Another intense peak at 37.9 corresponds to (210) and at $32.2^{\circ}, 50.7^{\circ}$ and $61.1^{\circ}$ and correspond to (200), (220) and (023) planes respectively represent the PbO formation by JCPDS analysis (card no. 050570). So, the XRD pattern of the powder sample clearly indicates the formation two forms of lead oxides. Both forms are insoluble in water. This type of reaction is known as disproportion reaction.

Lead ion is a very toxic compound which has bactericidal effect. It thus created a clear zone of inhibition on the culture plate against the E. coli (JMJ101) bacterial growth (Figure 6). But no such zone of inhibition was observed when supernatant (which was obtained after filtration of lead oxide nanoplates from the solution) was added to the wells of the E. coli bacterial growth containing agar plate. This result tells us that the bactericidal effect of the lead ions is lost due to the absence of lead ions in the supernatant. The MDH1 bacterial protein dissociates lead ions from its solution through the formation of lead oxide nanoplates.

The release of dye effluents from textile industry is a major source of water pollution. Presence of dyes in waste water would have harmful effect on aquatic system. Methyl Orange (MO) and Bromophenol Blue (BB) dyes are the pollutants of waste water, foods, cosmetics, agriculture and have a potential threat to the environment. The treatments for removing $\mathrm{MO}$ and $\mathrm{BB}$ dyes are therefore highly desirable. The catalytic degradation of these dye using nanoparticles is one of the most important and useful method for removing dyes from our envi- 
ronment. Our results showed that lead-oxide nanoplates had the Photo-catalytic ability for which it degraded $\mathrm{MO}$ and BB dye as described in Figures 7(a)-(d) respectively. The percentage of degradation ability of lead-oxide nanoplates was also calculated using Equation (1) and the percentage degradation spectra of $\mathrm{MO}$ and BB dyes were also shown in Figure 7(c) and Figure 7(d) respectively. These data and spectrum conclude the fact that bio-synthesized lead-oxide nanoplates are one of the effective photo catalyst. Chowdhury et al. (2015) have established that the hot spring bacterium BKH1 secretes bioremediase protein (molecular weight of $28 \mathrm{kDa}$ ) in the growth medium, which possess silica leaching activity [34]. They have proposed the mechanism of action of bioremediase protein against silica nanoparticles formation in biosilicification process. We also hypothesize similar type of action is taking place by the hot spring MDH1 bacterial protein against the formation of lead nanoplates. The actual mechanism of action of the protein against lead nanoplates formation will be established and reported in future.

\section{Conclusion}

The work demonstrated here is a facile and eco-efficient route for the removal of lead contamination from water by using a simple biological template. The results from different experiments confirm that the MDH1 microbial protein has the ability for formation of lead-oxide nanoplates from lead nitrate solution. The prepared lead oxide nanoplates also possess photo catalytic property due to which it can degrade several dyes (like MO and BB etc.) and be used for the removal of those dyes from several industrial effluents. The MDH1 microbial protein is thus very useful for cleaning of lead contaminated water as well as BB and MO contaminated industrial effluents, foods and several agricultural products.

\section{Funding Information}

The financial support from WOS-A Scheme (Ref. SR/WOS-A/PM-43/2018) from Department of Science and Technology, Government of India, New Delhi is gratefully acknowledged. Authors are grateful for the experimental and technical supports provided by the Biophysics Laboratory, Department of Physics, Jadavpur University.

\section{Conflicts of Interest}

There is no conflict of interest of any kind related to this work.

\section{Availability of Data and Material}

All the data obtained from several experiments are presented within the text of the manuscript.

\section{Code Availability}

NA. 


\section{Authors' Contributions}

BDC and AT conceived and designed the study. CG and SG conducted all the experimental work. CG also contributed new reagents or analytical tools. CG and $\mathrm{AT}$ analyzed the experimental data. BDC wrote the manuscript. All authors read carefully and approved the manuscript.

\section{Ethics Approval}

NA.

\section{Consent to Participate}

NA.

\section{Consent for Publication}

All the authors have given their consent to publish the article.

\section{References}

[1] Reza, R. and Singh, G. (2010) Heavy Metal Contamination and Its Indexing Approach for River Water. International Journal of Environmental Science and Technology, 7, 785-792. https://doi.org/10.1007/BF03326187

[2] Sparks, D.L. (2004) Toxic Metals in the Environment: The Role of Surfaces. Elements, 1, 193-197. https://doi.org/10.2113/gselements.1.4.193

[3] Jarosławiecka, A. and Piotrowska-Seget, Z. (2014) Lead Resistance in Micro-Organisms. Microbiology, 160, 12-25. https://doi.org/10.1099/mic.0.070284-0

[4] Singh, A.K., Srivastav, S.C., Verma, P., Ansari, A. and Verma, A. (2014) Hazard Assessment of Metals in Invasive Fish Species of the Yamuna River, India in Relation to Bioaccumulation Factor and Exposure Concentration for Human Health Implications. Environmental Monitoring and Assessment, 186, 3823-3836.

https://doi.org/10.1007/s10661-014-3660-6

[5] Aktar, M.W., Paramasivam, M., Ganguly, M., Purkait, S. and Sengupta, D. (2010) Assessment and Occurrence of Various Heavy Metals in Surface Water of Ganga River around Kolkata: A Study for Toxicity and Ecological Impact. Environmental Monitoring and Assessment, 160, 207-213.

https://doi.org/10.1007/s10661-008-0688-5

[6] Jaishankar, M., Tseten, T., Anbalagan, N., Mathew, B.B. and Beeregowda, K.N. (2014) Toxicity, Mechanism and Health Effects of Some Heavy Metals. Interdisciplinary Toxicology, 7, 60-72. https://doi.org/10.2478/intox-2014-0009

[7] Wai, K., Mar, O., Kosaka, S., Umemura, M. and Watanabe, C. (2017) Prenatal Heavy Metal Exposure and Adverse Birth Outcomes in Myanmar: A Birth-Cohort Study. International Journal of Environmental Research and Public Health, 14, Article No. 1339. https://doi.org/10.3390/ijerph14111339

[8] Neal, A.P. and Guilarte, T.R. (2010) Molecular Neurobiology of lead $\left(\mathrm{Pb}^{2+}\right)$ : Effects on Synaptic Function. Molecular Neurobiology, 42, 151-160.

https://doi.org/10.1007/s12035-010-8146-0

[9] Liu, L.E., Liu, J., Li, H., Zhang, H., Liu, J. and Zhang, H. (2012) Equilibrium, Kinetic, and Thermodynamic Studies of Lead (II) Biosorption on Sesame Leaf. BioResources, 7, 3555-3572. 
[10] Yamamura, S. (1984) Guidelines for Drinking Water Quality. World Health Organization, Geneva.

[11] Flora, S.J.S., Flora, G. and Saxena, G. (2006) Environmental Occurrence, Health Effects and Management of Lead Poisoning. In: José, S.C. and José, S., Eds., Lead. Elsevier, Amsterdam, 158-228. https://doi.org/10.1016/B978-044452945-9/50004-X

[12] Chen, Y., Pan, B., Li, H., Zhang, W., Lv, L. and Wu, J. (2010) Selective Removal of $\mathrm{Cu}$ (II) Ions by Using Cation-Exchange Resin-Supported Polyethyleneimine (PEI) Nanoclusters. Environmental Science \& Technology, 44, 3508-3513. https://doi.org/10.1021/es100341x

[13] Ahmad, R. and Haseeb, S. (2016) Kinetic, Isotherm and Thermodynamic Studies for the Removal of $\mathrm{Pb}^{2+}$ Ion by a Novel Adsorbent Luffa acutangula (LAPR). Desalination and Water Treatment, 57, 17826-17835. https://doi.org/10.1080/19443994.2015.1088476

[14] Bhatluri, K.K., Manna, M.S., Saha, P. and Ghoshal, A.K. (2014) Supported Liquid Membrane-Based Simultaneous Separation of Cadmium and Lead from Wastewater. Journal of Membrane Science, 459, 256-263. https://doi.org/10.1016/j.memsci.2014.02.019

[15] Rao, M.M., Ramana, D.K., Seshaiah, K., Wang, M.C. and Chien, S.C. (2009) Removal of Some Metal Ions by Activated Carbon Prepared from Phaseolus aureus Hulls. Journal of Hazardous Materials, 166, 1006-1013. https://doi.org/10.1016/j.jhazmat.2008.12.002

[16] Jawor, A. and Hoek, E.M. (2010) Removing Cadmium Ions from Water via Nanoparticle-Enhanced Ultrafiltration. Environmental Science \& Technology, 44, 2570-2576. https://doi.org/10.1021/es902310e

[17] Ofomaja, A.E., Naidoo, E.B., Modise, S.J. (2010) Biosorption of Copper (II) and Lead (II) onto Potassium Hydroxide Treated Pine Cone Powder. Journal of Environmental Management, 91, 1674-1685. https://doi.org/10.1016/j.jenvman.2010.03.005

[18] Parga, J.R., Cocke, D.L., Valenzuela, J.L., Gomes, J.A., Kesmez, M., Irwin, G. and Weir, M. (2005) Arsenic Removal via Electrocoagulation from Heavy Metal Contaminated Groundwater in La Comarca Lagunera Mexico. Journal of Hazardous Materials, 124, 247-254. https://doi.org/10.1016/j.jhazmat.2005.05.017

[19] Kapoor, A. and Viraraghavan, T. (1995) Fungal Biosorption-an Alternative Treatment Option for Heavy Metal Bearing Wastewaters: A Review. Bioresource Technology, 53, 195-206. https://doi.org/10.1016/0960-8524(95)00072-M

[20] Hussein, H., Fara, S. and Moawad, H. (2003) Isolation and Characterization of Pseudomonas Resistant to Heavy Metals Contaminants. Arab Journal of Biotechnology, 7, 13-22. https://doi.org/10.2225/vol7-issue1-fulltext-2

[21] Alam, N., Sarkar, M., Chowdhury, T., Ghosh, D. and Chattopadhyhay, B.D. (2016) Characterization of a Novel MDH1 Bacterium from a Virgin Hot Spring Applicable for Gold Nanoparticle (GNPs) Synthesis. Advances in Microbiology, 6, 724-732. https://doi.org/10.4236/aim.2016.69071

[22] Biswas, M., Majumdar, S., Chowdhury, T., Chattopadhyhay, B.D., Mandal, S., Halder, U. and Yamasaki, S. (2010) Bioremediase a Unique Protein from a Novel Bacterium BKH1, Ushering a New Hope in Concrete Technology. Enzyme and Microbial Technology, 46, 581-587. https://doi.org/10.1016/j.enzmictec.2010.03.005

[23] Gu, Z., Aikebaier, Y., Arefieva, V. and Mazirov, M. (2017) Using Microbiological Leaching Method to Remove Heavy Metals from Sludge. Eurasian Journal of Soil Science, 6, 51. https://doi.org/10.18393/ejss.284265 
[24] Meger, S.A. (1986) Polluted Precipitation and the Geochronology of Mercury Deposition in Lake Sediment of Northern Minnesota. In: Martin, H.C., Ed., Acidic Precipitation, Springer, Dordrecht, 411-419. https://doi.org/10.1007/978-94-009-3385-9 41

[25] Pongratz, R. and Heumann, K.G. (1999) Production of Methylated Mercury, Lead, and Cadmium by Marine Bacteria as a Significant Natural Source for Atmospheric Heavy Metals in Polar Regions. Chemosphere, 39, 89-102.

https://doi.org/10.1016/S0045-6535(98)00591-8

[26] Maher, W.A. (1981) Determination of Inorganic and Methylated Arsenic Species in Marine Organisms and Sediments. Analytica Chimica Acta, 126, 157-165. https://doi.org/10.1016/S0003-2670(01)83938-6

[27] Al-Rubaie, A.S.A. and Al-Kubaisi, A.R.A. (2015) Removal of Lead from Water by Using Aquatic Plants (Ceratophyllum demersum and Eichhorina crassipes). International Journal of Current Microbiology and Applied Sciences, 4, 45-51.

[28] Chand, V. and Prasad, S. (2013) ICP-OES Assessment of Heavy Metal Contamination in Tropical Marine Sediments: A Comparative Study of Two Digestion Techniques. Enzyme and Microbial Technology, 111, 53-61.

https://doi.org/10.1016/j.microc.2012.11.007

[29] Sarkar, M., Adak, D., Tamang, A., Chattopadhyay, B.D. and Mandal, S. (2015) Genetically-Enriched Microbe-Facilitated Self-Healing Concrete-A Sustainable Material for a New Generation of Construction Technology. RSC Advances, 5, 105363-105371. https://doi.org/10.1039/C5RA20858K

[30] Sarkar, M., Chowdhury, T., Chattopadhyhay, B.D., Gacchhui, R. and Mandal, S. (2014) Autonomous Bioremediation of a Microbial Protein (Bioremediase) in Pozzolana Cementious Composite. Journal of Materials Science, 49, 4461-4468. https://doi.org/10.1007/s10853-014-8143-1

[31] Sarkar, A., Chatterjee, A., Mandal, S. and Chattopadhyhay, B.D. (2019) An Alkaliphilic BacteriumBKH4 of Bakreshwar Hot Spring Pertinent to Bio-Concrete Technology. Journal of Applied Microbiology, 126, 1742-1750. https://doi.org/10.1111/jam.14236

[32] Show, S., Tamang, A., Chowdhury, T., Mandal, D. and Chattopadhyhay, B.D. (2015) Bacterial (BKH1) Assisted Silica Nanoparticles from Silica Rich Substrates: A Facile and Green Approach for Biotechnological Applications. Colloids and Surfaces B, 126, 245-250. https://doi.org/10.1016/j.colsurfb.2014.12.039

[33] Akhtar, M.S., Panwar, J. and Yun, S.Y. (2013) Biogenic Synthesis of Metallic Nanoparticles by Plant Extracts. ACS Sustainable Chemistry \& Engineering, 1, 591-602. https://doi.org/10.1021/sc300118u

[34] Chowdhury, T., Sarkar, M., Chaudhuri, B., Chattopadhyhay, B.D. and Halder, U.C. (2015) Participatory Role of Zinc in Structural and Functional Characterization of Bioremediase: A Unique Thermostable Microbial Silica Leaching Protein. Journal of Biological Inorganic Chemistry, 20, 791-803. https://doi.org/10.1007/s00775-015-1266-2 